\title{
INFLUENCE OF COMMONLY USED HEAT TREATMENTS OF ROW MILK ON PRESENCE AND NUMBER OF COAGULASE-POSITIVE STAPHYLOCOCCI
}

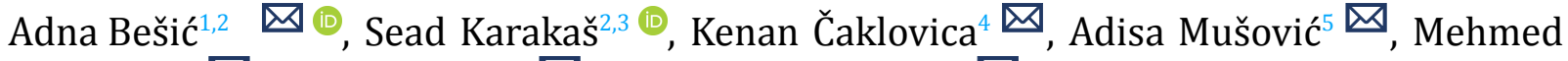 \\ Sultanović $^{\square}$, Alisa Smajović ${ }^{6}$ and Muhamed Katica ${ }^{7}$ \\ ${ }^{1}$ Public Health Institute FB\&H, Sarajevo, Bosnia \& Herzegovina \\ ${ }^{2}$ University "Vitez", Travnik, Bosnia \& Herzegovina \\ ${ }^{3}$ Public Health Institute SBK/KSB, Travnik, Bosnia \& Herzegovina \\ ${ }^{4}$ Department of Food Hygiene \& Technology, Veterinary Faculty, University, Sarajevo, Bosnia \& Herzegovina \\ ${ }^{5}$ Department, Euroinspekt d.o.o., Microbiological Laboratory, Sarajevo, Bosnia \& Herzegovina \\ ${ }^{6}$ Faculty of Pharmacy, University of Sarajevo, Bosnia \& Herzegovina \\ ${ }^{7}$ Department of Pathophysiology, Veterinary Faculty, University Sarajevo, Bosnia \& Herzegovina
}

Received 8 June 2021

Accepted 19 June 2021

Published 30 June 2021

Corresponding Author

Adna Bešić, a.besic@zzjzfbih.ba

DOI $10.29121 /$

granthaalayah.v9.i6.2021.4036

Funding: This research received no specific grant from any funding agency in the public, commercial, or not-for-profit sectors.

Copyright: (C) 2021 The Author(s). This is an open access article distributed under the terms of the Creative Commons Attribution License, which permits unrestricted use, distribution, and reproduction in any medium, provided the original author and source are credited.

\section{ABSTRACT}

Motivation/Background: Coagulase positive staphylococci (CPS) are common contaminants of raw milk. Before it is used, various heat treatments are applied to destroy microorganisms, inactivate enzymes and improve technological properties and concentration of dry matter of milk. This work aimed to determine the influence of commonly used heat treatments in diary industy on presence and number CPS in raw milk from Bosnia and Herzegovina area and to affirm whether there is a difference in efficacy between different treatments.

Method: Using the standard method, 40 samples of raw milk from farms were inoculated for counting the initial number of CPS in raw milk. Samples were then exposed to heat treatments in vapor sterilizer and CPS number was counted using the same standard method.

Results: Applied treatments included heat treatments at: $68{ }^{\circ} \mathrm{C} / 40 \mathrm{~s}, 70$ ${ }^{\circ} \mathrm{C} / 15 \mathrm{~s}, 72{ }^{\circ} \mathrm{C} /$ without holding, $63{ }^{\circ} \mathrm{C} / 30 \mathrm{~min}$ and $72{ }^{\circ} \mathrm{C} / 15 \mathrm{~s}$. CPS presence was detected in all tested samples of raw milk in numbers ranging from 2,82 to 5,32 , with an average of 4,30, calculated as $\log 10 \mathrm{cfu} / \mathrm{ml}$.

Conclusions: Raw milk samples collected in the field initially registered a high CPS number. The applied heat treatments were effective to a large extent. The initial CPS count of milk seems to be the most important factor determining the number of CPS after heat treatments as well as traits of the strains.

Keywords: Raw Milk, Coagulase Positive Staphylococci, Heat Treatment, Foodborne Diseases, Diary Industy 


\section{INTRODUCTION}

Foodborne bacterial diseases have become a worldwide concern which highlighted the importance of prevention, prediction as well as the role of control and management of foodborne bacterial diseases. The ongoing discussion is related to food matrices because of its complex and highly variable nature affecting the expression of virulence in different and unpredictable ways. Staphylococcus aureus (S. aureus) is opportunistic pathogen, gram-positive and coccus-shaped bacterium (1). Most of the diseases that originate from food are related to thermostable toxins that are produced from such kind of pathogen microorganisms (2). From a public health policy framework perspective, among many others foodborne pathogens, S. aureus is recognized as the most common worldwide cause of diseases. Hence, prevention measures which include detection of bacteria became a very important factor in food safety policy (3). There are many reports regarding health problems related to staphylococcal food poisoning which are caused by staphylococcal enterotoxin (SEs) but there are also heterogeneous results regarding dose levels of such enterotoxins that contaminate food (4). S aureus and many other microorganisms are easy to cultivate in milk, as an ideal medium (5). Typical diseases caused by S. aureus vary from skin lesions to septicaemia or meningitis. Besides inframammary infection sources, namely mammary secretions as the most common source of prevalence of Staphylococcus pathogen, there are many others such as teat canal, skin and other environmental sources. This qualifies S. aureus as the key pathogen responsible for dairy cow mastitis (7). S. aureus is usually divided into coagulase-negative staphylococci (CNS) and coagulase-positive staphylococci (CPS) (8). The presence of S. aureus in raw milk, in general, originates from cows with mastitis, from handlers or deficient hygiene. It presents a real problem in diary industry since it can occur in any phase of the diary production process. This means that levels of contamination with this pathogen grows rapidly in raw milk in particular, not only because of handlers and environment contamination but as a consequence of subclinical or clinical bovine mastitis as well. S. aureus can be shed into the milk (9) and produce SEs which represents the most common source of raw milk poisoning (10). Cheese can be detected as a source of $\mathrm{S}$. aureus if it is produced from staphylococcal contaminated milk without pasteurization, and with inadequate starter culture activity, or contaminated due to unappropriated conditions for processing and storage of the product (11).

The quality of cheese depends on the microbiological quality of milk, especially in the production of cheese from raw milk. It is considered that unpasteurized raw milk cheese products are more preferred because of their stronger and richer flavour or preserved natural properties of microflora and because of reduced levels of harmful microorganisms due to ripening process (12). However, when both pasteurized milk and milk products are produced, the microbiological quality of milk must be high, because high-temperature milk processing is not applied in the area of cheese production. 
High temperatures, in dairy production, are used to eliminate microorganisms, inactivate enzymes, improve the technological properties and concentration of dry matter of milk. They are very important and play the most important role in milk processing. The milk can be heat treated with the methods of thermalization and pasteurization. The thermalization and pasteurization of raw milk are carried out during cheese production to improve biological quality of milk and final product. Pathogen microorganisms as well as other microorganisms are present in raw milk cheese and pasteurized milk products during production (13).

Pasteurization can be carried out at temperatures from $63^{\circ} \mathrm{C}$ to $74^{\circ} \mathrm{C}$. Unlike pasteurization, sterilization is carried out at higher temperatures of $120^{\circ} \mathrm{C}$ to $140{ }^{\circ} \mathrm{C}$ (14). Recently it became common practice to use higher temperatures with shorter duration which has also resulted with improved or at least same levels of microorganisms, termination and inactivation of ferments without organoleptic changes in milk.

Thermalization process differs and includes different or separate procedures: heating at $72{ }^{\circ} \mathrm{C}$ without retention; heating at $70{ }^{\circ} \mathrm{C}$ for 15 seconds; heating at 68 ${ }^{\circ} \mathrm{C}$ for 40 seconds. There are also different types of pasteurization process common for cheese production: low pasteurization at $63^{\circ} \mathrm{C}$ for 30 minutes (used if the lipase is to be preserved in milk), medium pasteurization on at least $72{ }^{\circ} \mathrm{C}$ for at least $5 \mathrm{sec}$ onds (plate pasteurization), high pasteurization at $85^{\circ} \mathrm{C}$ for 1 minute (used only in production fermented dairy products because it reduces the coagulation properties of milk) (15).

This work aimed to determine the influence of commonly used heat treatments in diary industy on presence and number CPS in raw milk from Bosnia and Herzegovina area and to affirm whether there is a difference in efficacy between different treatments.

\section{MATERIALS AND METHODS}

\section{Milk samples}

40 samples of raw milk were collected from farms in Bosnia and Herzegovina and transported to the microbiological laboratory. The samples were collected and processed in the period from 1 May - 15 May 2019.

\section{Heat treatment}

After inoculation for counting the initial number of CPS in raw milk, samples were exposed to heat treatments in vapor sterilizer. During treatments, temperatures of milk samples were monitored using calibrated thermocouples. Applied treatments included temperature points at $68{ }^{\circ} \mathrm{C} / 40 \mathrm{~s}, 70{ }^{\circ} \mathrm{C} / 15 \mathrm{~s}$ and $72{ }^{\circ} \mathrm{C}$ /without holding, $63{ }^{\circ} \mathrm{C} / 30 \mathrm{~min}$ and $72{ }^{\circ} \mathrm{C} / 15 \mathrm{~s}$.

\section{Enumeration of CPS}

The number of CPS in raw and heat-treated milk was determined based on valid standard method BAS EN ISO 6888-1:2005 (16). After making initial suspensions 
and further decimal dilutions up to 10-6, $1 \mathrm{ml}$ initial suspension and all consecutive dilutions of milk samples were pipetted on Baird-Parker agar, per surface of 3 (90 $\mathrm{mm}$ diameter) agar plates, in duplicate (6 plates), spread with a sterile smear and incubated for $24 \pm 2 \mathrm{~h}$ in an incubator set at temperature at $37^{\circ} \mathrm{C}$. The same procedure was applied to raw milk samples and milk samples after heat treatments. CPS was recognized as black or grey, shiny and convex colonies 1 to $1.5 \mathrm{~mm}$ in diameter, surrounded by an opaque halo. Typical and atypical colonies of CPS were further confirmed by transferring from the surface of each selected colony an inoculum with a sterile inoculating loop to a Brain-heart infusion (BHI) broth. Incubation was at 35 ${ }^{\circ} \mathrm{C}$ or $37{ }^{\circ} \mathrm{C}$ for $24 \mathrm{~h} \pm 2 \mathrm{~h}$. Under aseptic conditions, $0.1 \mathrm{ml}$ of the resulting culture was added to $0.3 \mathrm{ml}$ of rabbit plasma in a sterile tube and incubated at $35{ }^{\circ} \mathrm{C}$ or 37 ${ }^{\circ} \mathrm{C}$. After 4 to $6 \mathrm{~h}$ of incubation, the presence of coagulation (plasma patch) was monitored. The coagulase test was positive if the amount of clot occupied more than $\frac{1}{2}$ of the original fluid volume.

\section{Statistical analysis}

Statistical analysis of the data was performed in IBM SPSS Statistics 24 (IBM Corp. Released 2016. IBM SPSS Statistics for Windows, Version 24.0. Armonk, NY: IBM Corp.) using the Jonckheere - Terpstra test, bearing in mind that data distribution is not normal $(\mathrm{p}<0.000)$ as determined by the Shapiro-Wilk test. A statistically significant difference is determined based on the $\mathrm{p}<0.05$ value.

\section{RESULTS AND DISCUSSIONS}

Relevant data on the presence and number of CPS in milk samples after treatments are shown in Table 1.

Table 1 Presence and number of coagulase-positive staphylococci in milk after applied heat treatments

\begin{tabular}{|c|c|c|c|c|c|c|c|c|c|}
\hline \multirow{3}{*}{$\begin{array}{l}\text { CPS number } \\
\text { after } \\
\text { treatment }\end{array}$} & \multicolumn{7}{|c|}{ Treatments } & \multirow{2}{*}{\multicolumn{2}{|c|}{$\begin{array}{c}72{ }^{\circ} \mathrm{C} / \\
15 \mathrm{~s}\end{array}$}} \\
\hline & $\begin{array}{c}63{ }^{\circ} \mathrm{C} / 30 \\
\min \end{array}$ & $68^{\circ}$ & $\mathrm{C} / 40 \mathrm{~s}$ & $70^{\circ}$ & $\mathrm{C} / 15 \mathrm{~s}$ & $\begin{array}{r}72 \\
\text { wit } \\
\text { hol }\end{array}$ & $\begin{array}{l}{ }^{\circ} \mathrm{C} / \\
\text { hout } \\
\text { ding }\end{array}$ & & \\
\hline & $\begin{array}{ll}\text { CFU/ } & \log 10 \\
& \mathrm{CFU} / \mathrm{ml}\end{array}$ & $\begin{array}{c}\mathrm{CFU} / \\
\mathrm{ml}\end{array}$ & $\begin{array}{l}\log 10 \\
\mathrm{CFU} / \mathrm{ml}\end{array}$ & CFU/ & $\begin{array}{l}\log 10 \\
\mathrm{CFU} / \mathrm{ml}\end{array}$ & CFU/ & $\begin{array}{l}\log 10 \\
\mathrm{CFU} / \mathrm{ml}\end{array}$ & CFU/ & $\begin{array}{l}\log 10 \\
\mathrm{CFU} / \mathrm{ml}\end{array}$ \\
\hline Mean & $121.6 \quad 1.10$ & 189.6 & 1.16 & 51.47 & 0.98 & 41.42 & 0.75 & 10.87 & 1.04 \\
\hline SD & 318.1 & 410.8 & 1.08 & 101.1 & 0.83 & 105 & 0.88 & 18.72 & 1,27 \\
\hline MIN & 0.00 & 0.00 & 0.00 & 0.00 & 0.00 & 0.00 & 0.00 & 0.00 & 0.00 \\
\hline MAX & 1600 & 1800 & 3.26 & 470 & 2.67 & 580 & 2.76 & $85.0 \mathrm{C}$ & 1,93 \\
\hline
\end{tabular}

CPS presence was detected in all tested samples of raw milk in numbers ranging from $6.6 \times 10^{2}-2.1 \times 10^{5} \mathrm{cfu} / \mathrm{ml}$, with an average value of $4.4 \times 10^{4}$. Calculated as $\log 10 \mathrm{cfu} / \mathrm{ml}$, the number of CPS in raw milk samples ranged between 2.82 and 5.32, 
with an average of 4.30 (Figure 1 ).

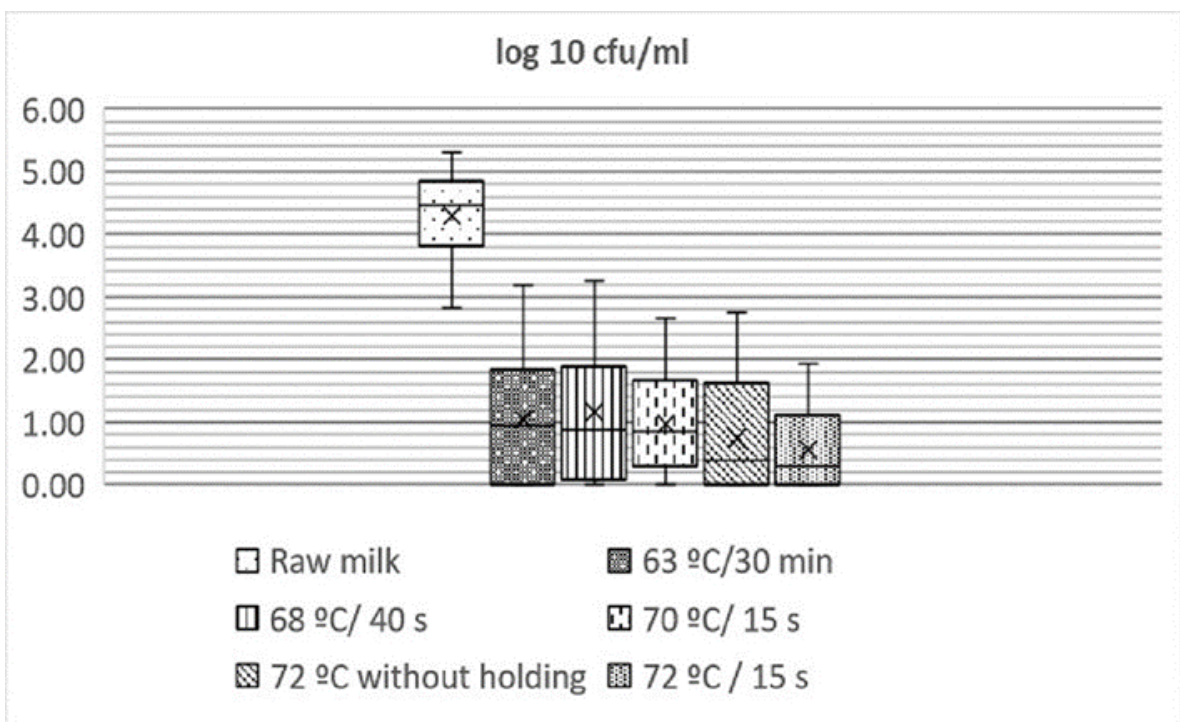

Figure 1 Comparation of CPS number (as $\log 10 \mathrm{cfu} / \mathrm{ml}$ ) in raw milk before and after applied heat treatments

After heat treatments have been applied, reduction in presence and number of CPS is visible. CPS was not detected in 11 samples after heat treatmen at $63{ }^{\circ} \mathrm{C} / 30$ min and in 7 samples CPS viability reduction was $99.99 \%$ or higher (Figure 2 .). The average reduction in viability after this treatment was $99.34 \%$, with a minimum of $87.88 \%$. Treatment at $68{ }^{\circ} \mathrm{C} / 40 \mathrm{~s}$ resulted in total viability reduction of CPS in 9 samples and in 6 samples this reduction was $99.99 \%$ or higher. Minimal reduction in CPS number was $92.12 \%$ and an average $99.37 \%$. CPS was not detected in 9 samples after treatment at $70{ }^{\circ} \mathrm{C} / 15 \mathrm{~s}$, with reduction of $99.99 \%$ or higher in 4 samples. Minimal viability reduction was $90.91 \%$ and an average $99.59 \%$. Total viability reduction after heat treatment at $72^{\circ} \mathrm{C}$ without holding was detected in 18 samples and 2 samples was $99.99 \%$ or higher. Minimal viability reduction after this heat treatment was $88.33 \%$ and average $99.63 \%$. CPS was not detected in 17 samples after heat treatment at $72{ }^{\circ} \mathrm{C} / 15 \mathrm{~s}$ and in 4 samples CPS viability reduction was $99.99 \%$ or higher. This treatment demonstrated the highest minimal viability reduction (95.78\%) and the highest average reduction in CPS number (99.84\%), while the lowest values of viability reduction were detected after heat tretment at $63^{\circ} \mathrm{C} / 30 \mathrm{~min}$ (Figure 2 ).

Each of two treatments at $72{ }^{\circ} \mathrm{C}$ resulted in viability reduction lower than $99.9 \%$ in only one sample, while in the rest of treated samples, the reduction in CPS number was higher than $99.9 \%$. Lowest viability reductions and the number of samples with total viability reduction are seen in treatments at $63{ }^{\circ} \mathrm{C} / 30 \mathrm{~min}$ and $68^{\circ} \mathrm{C} / 40 \mathrm{~s}$.

After statistical analysis, it can be concluded that the results indicate that there was a statistically significant difference before and after treatment of the sample with $68{ }^{\circ} \mathrm{C} / 40 \sec (\mathrm{p}=0.003)$ and before and after treatment with $72^{\circ} \mathrm{C} /$ without holding 

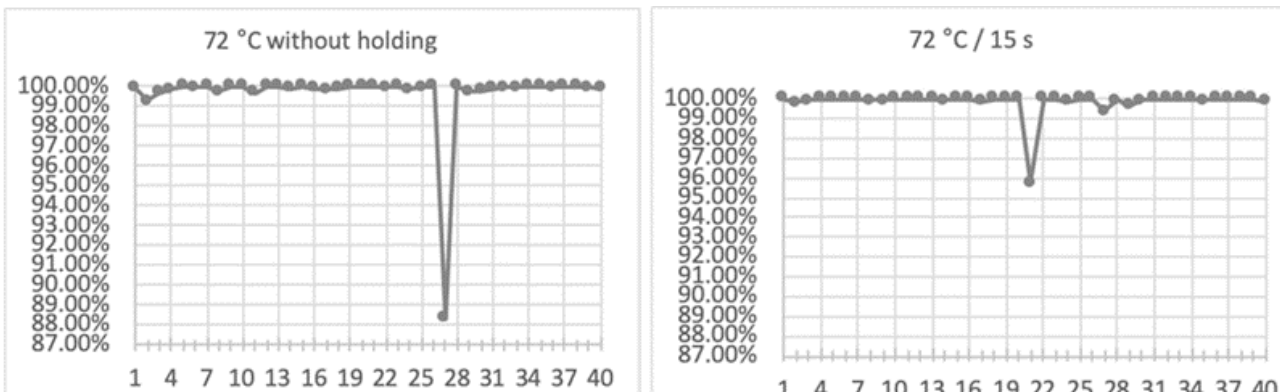

$1 \quad 4 \quad 71013161922252831343740$

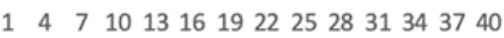
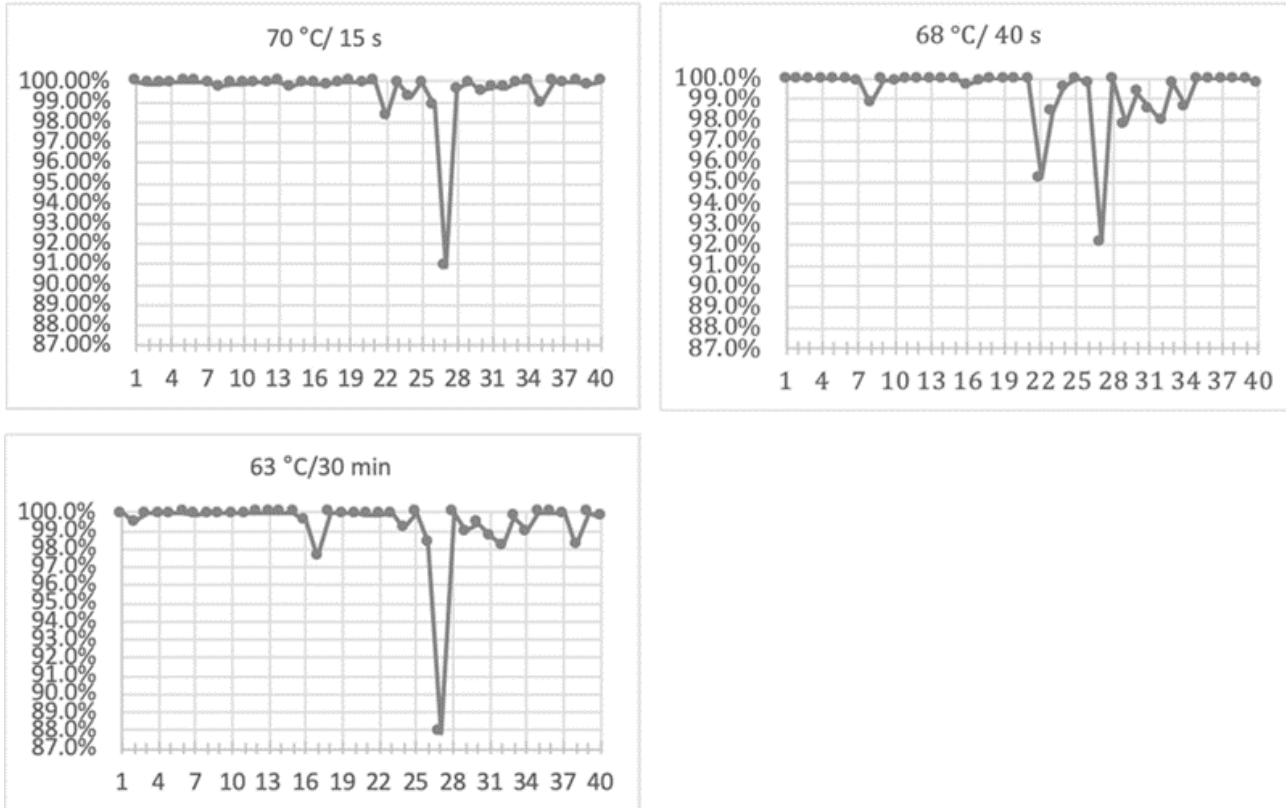

Figure 2 Comparison of CPS viability reduction after applied heat treatments

$(\mathrm{p}=0.020)$. Although the results after treatment at $70^{\circ} \mathrm{C} / 15 \mathrm{sec}$ have a rather low $\mathrm{p}$ - value $(\mathrm{p}=0.067)$, it cannot be considered statistically relevant (Table 2 ).

\begin{tabular}{cc}
\hline $\begin{array}{l}\text { Table } 2 \text { Statistical analysis } \\
\text { parameters }\end{array}$ & tested \\
\hline Analysis & p-value \\
\hline Raw milk $-63^{\circ} \mathrm{C} / 30 \mathrm{~min}$ & 0.424 \\
\hline Raw milk $-68^{\circ} \mathrm{C} / 40 \mathrm{sec}$ & 0.003 \\
\hline Raw milk $-70^{\circ} \mathrm{C} / 15 \mathrm{sec}$ & 0.067 \\
\hline Raw milk $-72{ }^{\circ} \mathrm{C} /$ without holding & 0.020 \\
\hline Raw milk $-72{ }^{\circ} \mathrm{C} / 15 \mathrm{sec}$ & 0.284 \\
\hline
\end{tabular}

The data obtained on the reduction of a number of CPS in row milk after different heat treatments at $68^{\circ} \mathrm{C} / 40 \mathrm{~s}, 70{ }^{\circ} \mathrm{C} / 15 \mathrm{~s}$ and $72{ }^{\circ} \mathrm{C} /$ without holding, $63^{\circ} \mathrm{C} / 30 \mathrm{~min}$ and $72{ }^{\circ} \mathrm{C} / 15 \mathrm{~s}$ are comparable, with some exceptions to the results obtained by other 
investigators. This bacterium produces a heat-stable enterotoxin which survives pasteurization although organism of the bacterium does not. When ingested, heat-stable enterotoxin can cause nausea, vomiting and diarrhoea. The most significant problem with CPS contamination occurs during cheesemaking, as most of the organisms are trapped in the curd (17). Applied heat treatments are used in cheese production and CPS can be present in cheese made of poor hygienic quality raw but even heat-treated milk. According to Commission Regulation (EC), cheeses made from milk that has undergone a lower heat treatment than pasteurisation and ripened cheeses made from milk or whey that has undergone pasteurisation or a stronger heat treatment, if values of CPS $>10^{5} \mathrm{cfu} / \mathrm{g}$ are detected, the cheese batch has to be tested for staphylococcal enterotoxins. Action in case of unsatisfactory results is improvements in production hygiene and selection of raw materials (18). Current United States Standards of Identity (19) permit treatment of the cheese milk with hydrogen peroxide and catalase specifically to reduce CPS numbers during the production of cheeses such as Cheddar and Colby.

Microbiological analysis of pasteurized milk indicated presence of pathogens like Staphylococcus sp., Salmonella sp. (20), coliform (21) from India, Salmonella (22) from Nigeria, Enterobacter spp., Escherichia coli from Jamaica (23), S. aureus from Brazil (24), coliform, Bacillus cereus from Kuwait (25) and Escherichia coli and S. aureus from Iran (26).

In our research, CPS has not been detected in 17 samples after heat treatment at $72{ }^{\circ} \mathrm{C} / 15 \mathrm{~s}$ and in 4 samples CPS viability reduction was $99.99 \%$ or higher (Figure 2 ). According to Holsinger et al. (27), pasteurized milk is usually considered pathogenfree except for the spores of Bacillus cereus if present in large numbers. Pearce et al. (28), reported kinetic data on the survival of a range of significant, the most heatresistant strain of milk-borne pathogens, such as S. aureus, under commercial-type pasteurization conditions. UHT (ultra-high temperature processing) milk was inoculated with the most heat-resistant pathogens at $\sim 10^{7} / \mathrm{mL}$ and heat-treated in a pilotplant-scale pasteurizer under commercial-type conditions of the turbulent flow for $15 \mathrm{~s}$ over a temperature range from 56 to $66^{\circ} \mathrm{C}$ and at $72{ }^{\circ} \mathrm{C}$. Survivors were enumerated on nonselective media chosen for the highest efficiency of plating of heatdamaged bacteria of each of the chosen strains. The mean $\log 10$ reductions and temperatures of inactivation of CPS during a 15-s treatment was $>6.7$ at $66.5^{\circ} \mathrm{C}$. In our research, after heat treatments at $63{ }^{\circ} \mathrm{C} / 30 \mathrm{~min}$ in 7 samples CPS viability reduction was $99.99 \%$ or higher, in 6 samples this reduction was $99.99 \%$ or higher after heat treatment at $68{ }^{\circ} \mathrm{C} / 40 \mathrm{~s}$, after treatment at $70{ }^{\circ} \mathrm{C} / 15 \mathrm{~s}$ the reduction was $99.99 \%$ or higher in 4 samples and two treatments at $72{ }^{\circ} \mathrm{C}$ resulted in viability reduction lower than $99.9 \%$ in only one sample. When calculating the magnitude of the change in cell number, microbiologists often use a logarithmic scale (log scale), so according to the translation of log reductions to percent reductions, $6 \log$ reduction $=99.9999 \%$ reduction. 
Out of 40 samples tested, 27 samples of raw milk had over 104 CPS, 11 samples of raw milk over $10^{3} \mathrm{CPS}$, and 2 analysed samples of raw milk over $500 \mathrm{cfu} / \mathrm{ml}$.

$\mathrm{S}$. aureus is a ubiquitous organism. It is frequently manually isolated from raw milk from individual animals, bulk raw milk and from the milk of dairy cattle suffering from mastitis. The typical counts of S. aureus are 100-200 cfu/ml in properly drawn milk. In the case of a contaminated udder, the counts may increase up to $10^{4} \mathrm{cfu} / \mathrm{ml}$ (29).

It can be concluded that the best treatment results under conditions of $68{ }^{\circ} \mathrm{C} / 40$ sec, followed by conditions $72{ }^{\circ} \mathrm{C}$ if $\mathrm{p}$ values and parameters from descriptive statistics are compared. The heat treatment of CPS bacteria at $80^{\circ} \mathrm{C}$ for 20 minutes allowed the protein to envelop the denatured S. aureus resulting in cell death. Protein will lose shape which will lead to decreased ability to protect the bacterial cell. The moment temperature reaches $80^{\circ} \mathrm{C}$, the cell will experience plasmolysis resulting in peeling of the cytoplasm membrane of the cell wall because of cytoplasm penetration. This will allow breakthrough of the liquid from outside into the cell and it will damage it, hence, heating can lead to the death of bacterial cells. The number of dead bacterial cells depends on the heating intensity and heating time (30). Research shows that the higher the temperature used, the shorter the time to kill bacteria, especially S. aureus. The usual time and temperatures pasteurization, $60-65^{\circ} \mathrm{C}$ for 30 minutes, cannot kill CPS producing enterotoxins. The optimal temperature and time to reduce the level of contamination in food products, especially milk products, is $80{ }^{\circ} \mathrm{C}$ for 20 minutes (31).

\section{CONCLUSIONS AND RECOMMENDATIONS}

It could be stated that traditional heat treatments are the exemplar methods for milk treatment. Raw milk samples collected in the field initially registered a high CPS number. The initial CPS count of milk seems to be the most important factor determining the number of CPS after heat treatments. The applied heat treatments were effective to a large extent. The ability of CPS colonies to survive even after heat treatments were applied may be due to traits of the strains, which needs to be explored in further studies.

\section{ACKNOWLEDGEMENTS}

The authors would like to thank the Institute of Public Health SBK / KSB for providing and collecting samples for conducting this research, as well as funding the necessary nutrient media and reagents. I would like to acknowledge my gratitude to Prof. Sead Karakaš, Director of the Institute of Public Health SBK / KSB, for his endless patience, useful advice and selfless leadership. 


\section{REFERENCES}

Abdolshahi, A., Naybandi-Atashi, S., Heydari-Majd, M., Salehi, B., Kobarfard, F., Ayatollahi, S. A., Ata, A., Tabanelli, G., Sharifi-Rad, M., Montanari, C., Iriti, M., \& Sharifi-Rad, J. (2018). Antibacterial activity of some Lamiaceae species against Staphylococcus aureus in yoghurt-based drink (Doogh). Cellular and Molecular Biology, 64(8), 71-71. Retrieved from https://dx.doi.org/10.14715/cmb/2018.64.8.11 10.14715/cmb/2018.64.8.11

Aglawe, P. P., \& Wadatkar, C. M. (2012). Microbial Examination Of Milk Sample From Nagpur Region With Reference To Coliform. Food Sci Technol Letters, 3, 24-30.

Al-Mazeedi, H. M., Gholoum, F. A., \& Akbar, B. H. (2013). Microbiological Status Of Raw And Pasteurized Milk In The State Of Kuwait. Int J Eng Sci, 3, 15-19.

Alnazeer, G. A., Muna, O. E., \& Mohammed, G. E. (2019). Antibiotic Resistance Pattern Of Staphylococcus Species Isolated From Raw Cow Milk In Ghebaish Locality. Sudan J Sci Technol, 20, 69-74.

Anderson, M., Hinds, P., Hurditt, S., Miller, P., McGrowder, D., \& Alexander-Lindo, R. (2011). The microbial content of unexpired pasteurized milk from selected supermarkets in a developing country. Asian Pacific Journal of Tropical Biomedicine, 1(3), 205-211. Retrieved from https://dx.doi.org/10.1016/s2221-1691(11)60028-2 10.1016/s2221 -1691(11)60028-2

Asperger, H., Zangerl, P., \& Aureus, S. (2003). Encyclopedia Of Dairy Science. In R. H, F. J, \& F. P (Eds.), (pp. 2563-2572). San Diego: Academic Press.

Baran, A., Erdogan, A., Turgut, T., \& Adiguzel, M. C. (2017). A Review On The Presence of Staphylococcus Aureus In Cheese. Turk J Nature Sci, 2, 100-105.

Code Of Federal Regulations-Cheddar Cheese. (2020). Retrieved from Https://Www .Accessdata.Fda.Gov/Scripts/Cdrh/Cfdocs/Cfcfr/Cfrsearch.Cfm?Fr=133.113

de Oliveira, L. P., e Barros, L. S. S., Silva, V. C., \& Cirqueira, M. G. (2011). Study of Staphylococcus aureus in raw and pasteurized milk consumed in the Reconcavo area of the State of Bahia, Brazil. Journal of Food Processing \& Technology, 02(06), 1-5. Retrieved from https://dx.doi.org/10.4172/2157-7110.1000128 10.4172/2157-7110.1000128

Fagundes, H., Barchesi, L., Filho, A. N., Ferreira, L. M., \& Oliveira, C. A. F. (2010). Occurrence of Staphylococcus aureus in raw milk produced in dairy farms in São Paulo state, Brazil. Brazilian Journal of Microbiology, 41(2), 376-380. Retrieved from https://dx.doi.org/ 10.1590/s1517-83822010000200018 10.1590/s1517-83822010000200018

Fletcher, S., Boonwaat, L., Moore, T., Chavada, R., \& Conaty, S. (2015). Investigating an outbreak of staphylococcal food poisoning among travellers across two Australian states. Western Pacific Surveillance and Response Journal, 6(2), 17-21. Retrieved from https:// dx.doi.org/10.5365/wpsar.2015.6.1.011 10.5365/wpsar.2015.6.1.011

Fox, P. F., Guinee, T. P., Cogan, T. M., \& Mcsweeney, P. L. (2017). Fundamentals Of Cheese Science. Springer.

Guidi, F., Duranti, A., Gallina, S., Nia, Y., Petruzzelli, A., Romano, A., Travaglini, V., Olivastri, A., Calvaresi, V., Decastelli, L., \& Blasi, G. (2018). Characterization of A Staphylococcal Food Poisoning Outbreak in A Workplace Canteen during the Post-Earthquake Reconstruction of Central Italy. Toxins, 10(12), 523-523. Retrieved from https://dx.doi.org/ 10.3390/toxins10120523 10.3390/toxins10120523

Havranek, J., Kalit, S., Antunac, N., Samarzija, D., Cheesemaking, \& Zagreb. (2014). Dairy Association.

HOLSINGER, V. H., RAJKOWSKI, K. T., \& STABEL, J. R. (1997). Milk pasteurisation and safety: a brief history and update. Revue Scientifique et Technique de l'OIE, 16(2), 441-451. 
Retrieved from https://dx.doi.org/10.20506/rst.16.2.1037 10.20506/rst.16.2.1037

Liu, H., Li, S., Meng, L., Dong, L., Zhao, S., Lan, X., Wang, J., \& Zheng, N. (2017). Prevalence, antimicrobial susceptibility, and molecular characterization of Staphylococcus aureus isolated from dairy herds in northern China. Journal of Dairy Science, 100(11), 87968803. Retrieved from https://dx.doi.org/10.3168/jds.2017-13370 10.3168/jds.2017 $-13370$

Microbiology Of Food And Animal Feeding Stuffs - Horizontal Method For The Enumeration Of Coagulase-Positive Staphylococci. (n.d.). BAS ISO 688-1:2008, 1.

Okpalugo, J., Ibrahim, K., Izebe, K. S., \& Inyang, U. S. (2008). Aspects of microbial quality of some milk products in Abuja Nigeria. Tropical Journal of Pharmaceutical Research, 7(4), 1169-1169. Retrieved from https://dx.doi.org/10.4314/tjpr.v7i4.14703 10.4314/ tjpr.v7i4.14703

On Microbiological Criteria For Foodstuffs. (2005)., 2005-2073.

Ozturkoglu-Budak, S., Vries, D., \& P, R. (2017). Mold-Ripened And Raw Milk Cheeses: Production, Risks, And Benefits To Human Health. In W. R, C. RJ, \& P. V (Eds.), Dairy In Human Health And Disease Across The Lifespan (pp. 353-61). Academic Press.

Panthi, R. R., Jordan, K. N., Kelly, A. L., \& Sheehan, J. J. (2017). Selection And Treatment Of Milk For Cheesemaking. Physics And Microbiology, 23-50.

Pearce, L. E., Smythe, B. W., Crawford, R. A., Oakley, E., Hathaway, S. C., \& Shepherd, J. M. (2012). Pasteurization of milk: The heat inactivation kinetics of milk-borne dairy pathogens under commercial-type conditions of turbulent flow. Journal of Dairy Science, 95(1), 20-35. Retrieved from https://dx.doi.org/10.3168/jds.2011-4556 10.3168/jds.2011 $-4556$

Peton, V., \& Loir, Y. L. (2014). Staphylococcus aureus in veterinary medicine. Infection, Genetics and Evolution, 21, 602-615. Retrieved from https://dx.doi.org/10.1016/j.meegid.2013 .08 .011 10.1016/j.meegid.2013.08.011

Rubab, M., Shahbaz, H. M., Olaimat, A. N., \& Oh, D.-H. (2018). Biosensors for rapid and sensitive detection of Staphylococcus aureus in food. Biosensors and Bioelectronics, 105, 49-57. Retrieved from https://dx.doi.org/10.1016/j.bios.2018.01.023 10.1016/j.bios .2018.01.023

Singh, V., Kaushal, S., Tyagi, A., \& Sharma, P. (2011). Screening Of Bacteria Responsible For The Spoilage Of Milk. J Chem Pharm Res, 3, 348-50.

Takahashi, I., \& Johns, C. K. (1959). Staphylococcus Aureus in Cheddar Cheese. Journal of Dairy Science, 42(6), 1032-1037. Retrieved from https://dx.doi.org/10.3168/jds .s0022-0302(59)90686-1 10.3168/jds.s0022-0302(59)90686-1

Vahedi, M., Nasrolahei, M., Sharif, M., \& Mirabi, A. M. (2011). Bacteriological Study Of Raw And Unexpired Pasteurized Cow's Milk Collected At The Dairy Farms And Super Markets In Sari City In. J Prev Med Hyg, 54, 120-123.

Wald, R., Hess, C., Urbantke, V., Wittek, T., \& Baumgartner, M. (2019). Characterization of Staphylococcus Species Isolated from Bovine Quarter Milk Samples. Animals, 9(5), 200200. Retrieved from https://dx.doi.org/10.3390/ani9050200 10.3390/ani9050200

Yaniarti, M. N., Amarantini, C., \& Budiarso, T. Y. (1908). The Effect Of Temperature And Pasteurization Time On Staphylococcus Aureus Isolates From Dairy Products. Of The 8th International Conference On Global Resource Conservation (ICGRC), 50003-50004.

Zeaki, N., Johler, S., Skandamis, P. N., \& Schelin, J. (2019). The Role of Regulatory Mechanisms and Environmental Parameters in Staphylococcal Food Poisoning and Resulting Challenges to Risk Assessment. Frontiers in Microbiology, 10, 1-13. Retrieved from https://dx.doi.org/10.3389/fmicb.2019.01307 10.3389/fmicb.2019.01307 